\begin{tabular}{lcl}
\hline Bentham OPen & The Open Sports Sciences Journal \\
\hline CrossMark & Content list available at: www.benthamopen.com/TOSSJ/ & DOI: $10.2174 / 1875399 X 01609010114$ \\
\hline
\end{tabular}

REVIEW ARTICLE

\title{
Recontextualization of Nomad Theories in the Development of Physical Education in France and Argentina, 1880-1940
}

\author{
Angela Aisenstein $^{2}$ and Jacques Gleyse ${ }^{*, 1}$

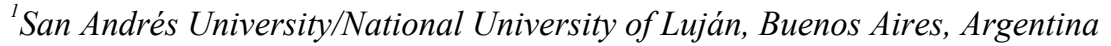 \\ ${ }^{2}$ Montpellier University and Paul Valery University Montpellier. ED 58.2 place Marcel Godechot 34092, Montpellier \\ Cedex 5, France
}

Received: September 09, 2015

Revised: January 20, 2016

Accepted: June 23, 2016

\begin{abstract}
This paper compares the ways in which Nomad discourses on the need to educate the human body were adopted and adapted with the development of physical education as a school subject in France and Argentina between 1880 and 1940 . The history of physical education during the nineteenth and twentieth centuries shows that many educational systems were created for educating the human body [1] as a special subject. The similarities between different countries in terms of the institutional context in which physical education was promoted, the scientific arguments that justified the need for physical education and the design of similar bodily practices aimed at educating the human body, support the claims made in neo-institutional theories about "world institutionalization of education" [2].
\end{abstract}

Keywords: History, Internationalization, Indigenization, Nomad practices and theories, Physical education.

\section{INTRODUCTION}

Although very different in terms of quality and quantity, there are a number of similarities between Argentina and France in the process of institutionalizing physical education in school in the late nineteenth and early twentieth centuries. Over and above the process of institutionalization certain ideas and practices travelled from one country to the other as part of a larger movement of political, scientific and educational ideas that were conceived as or considered to be modern from the end of the nineteenth and during the first decades of the twentieth century. In this sense the Paris International Conference on Physical Education in 1913 and the Conference on School Health and Hygiene in August 1910 (IIIème Congrès International sur l'hygiène scolaire) played an important role in enabling key players in the field to encourage the dissemination of ideas and practices and the early globalization of bodily, mechanical and machine metaphors and naturalist practices.

Both recent [3] and earlier work [4] has shown how these physical and sports education theories and practices travelled initially between various European countries, then between Western countries and subsequently worldwide. This evolution is identifiable from the physical exercise (Turnen) commended by Friedrich Ludwig Jahn (1778-1852) that was taken up in various European countries with propositions by the Spanish-born Francisco Amoros y Ondeano (1770-1848). The principle was adopted in Paris at the start of the nineteenth century and was at the origin of the first French non military gymnasium. Similarly, it made an appearance with the institution of the Swedish gymnasium of Per Henrik Ling (1776-1839) and the neo-Swedish method espoused in France [5] and a number of countries throughout the world, particularly in South America, in the nineteenth and early twentieth centuries.

Of course, it would not be valid to limit physical education to the strict sense of the term since we generally tend to

\footnotetext{
* Address correspondence to this author at the San Andrés University/National University of Luján, Buenos Aires, Argentina; E-mail: jacques.gleyse@orange.fr
} 
identify physical education and sports education, sport itself being the subject of globalization from its institutional birth in Great Britain. Yet other methods spread almost planet-wide, such as the method initiated by Georges Demenij (1850-1917) [6] and that promoted by Georges Hébert (1875-1957) [7], although they were clearly not as successful as either the Swedish method or the sports approach.

The article that follows, as other relatively recent work on the fecundity of the Hébert method in the south of Brazil and Argentina [8] and found in the early issues of the International Journal of Sport History [9], seeks to throw light on reciprocal influences or, more specifically, on the circulation of ideas and practices (Nomad theories) as well as the similarities and differences in the development of physical education in France and Argentina between 1880 and 1940.

A review of the work of physical education historians during the nineteenth and twentieth centuries in various countries has shown how in different ways each education system incorporated a specific subject to provide for educating the human body coincidentally with the passing of laws on compulsory school attendance within the framework of social, modernizing processes inspired by science [10]. Common aspects and similarities may be seen in terms of the political and institutional contexts in which they took place; the scientific support for the arguments that promoted and accompanied them and the identification of a social base or recipient for which similar body practices are designed or chosen may be sufficient indicators to sustain the hypothesis of Meyer, Kamens and Benavot [11] in a comparative study on the origin and enhancement of the curriculum for the masses during the period 1920-1986. This paper formulates the general guidelines existing in mass education and its programs, showing surprising degrees of homogeneity across the world. This approach enriched the perspective for study in the case of each nation, forcing us to consider the interplay of world forces that influenced a country's educational policies long before the current globalization phenomenon emerged. And from a different standpoint, the approach also enabled a certain relative autonomy of thinking in physical education, similar to that found in sport (and medicine), that would work better in association with the logic found in the field itself than with the rules or needs of social life in the context of each individual nation [12].

Focusing on the intention to understand what occurred in each country, how physical education in schools was conceived, what effect it had and on whom, this paper considers that such findings should be supplemented by referencing studies that compare countries, that grasp the recontextualization elements that defined and differentiated concrete institutional and educational practices in each nation and that are likely to continue doing so even within the framework of the globalization process. These elements are found in the nation's history and development, in its political structure and in related cultural variables, in the education systems themselves and among professional educational bodies such as teachers, administrators and inspectors.

\section{THE SOCIAL AND POLITICAL CONTEXT OF COMPULSORY SCHOOLING IN ARGENTINA AND FRANCE (1880-1914)}

In 1880 the state of development in the two countries was very different. Yet simultaneous laws in Argentina and France made schooling compulsory, the teaching of gymnastics became compulsory too. Intellectual, physical and moral education for all was legislated in both countries, as Emile Durkheim and Jules Ferry had hoped, as did even Emile Combes and earlier, Auguste Comte and Emile Littré. The term integrated education may be used on this subject. This idea spread around the planet through the process of colonization which, although in quite different forms, affected France and Argentina concomitantly.

In the case of Argentina, after the decades of civil war that followed the Declaration of Independence from Spain [13], the Nation State was consolidating and becoming the promoter and guarantor of progress thus affecting all aspects of national life. From a social perspective, mass immigration and economic progress profoundly remodeled Argentine society during the second half of the nineteenth century. With little more than 1.8 million inhabitants in 1869 , Argentina's population had increased to 7.885 million by 1914 . By 1880 in the city of Buenos Aires alone, a third of inhabitants were foreigners and towards 1914, this proportion had increased to encompass nearly half the population of the city; $43 \%$ of the population were immigrants. The social integration of immigrants and the achievement of a relative cultural homogeneity were paramount issues for the ruling class. With this objective in mind, important political and education debates took place and laws were passed in 1875 and 1905 organizing primary schooling. One of the most hotly debated topics during the process of drafting the Common Education Act was that of secularity and the role of the State in education. While the State was determined to integrate the immigrant population and education was considered a fundamental tool for social homogeneity, schools would not provide the teaching of any particular religion since that would violate the right to individual freedom guaranteed under the Constitution. 
According to the National Constitution enacted in 1853, the Republic of Argentina adhered to a federal form of government, delegating the organizing of primary education to each of its provinces. The first Common Education Act which established compulsory school attendance - was passed in the province of Buenos Aires in 1875. Some years later, in 1884, Common Education Act no 1420 proclaimed primary education as compulsory, free and neutral from the religious perspective [14] for the federal capital city and national territories. Finally, Act no 4874 passed in 1905 broadened the scope of the previous Act by authorizing the National Council of Education to open rural, mixed and elementary schools in provincial territories. In 1869 the first national census found that 1,830,000 [15] people were living in Argentina; 423,459 were children of school age, of which only 82,671 actually attended school; in 1909, according to a school census, 107,822 children attended school of the 182,750 children of school age [16].

Primary school, intended for children between 6 and 14 years old, consisted of three types of school (infants' school covering $1^{\text {st }}$ and $2^{\text {nd }}$ grades; elementary school covering $3^{\text {rd }}$ and $4^{\text {th }}$ grades, and upper school the $5^{\text {th }}$ and $6^{\text {th }}$ grades). The schools based in the capital city or in national territories were the responsibility of the National Council of Education; those created by provincial laws were the responsibility of respective provincial departments or administrative education offices but were supervised by a body of inspectors reporting to the national government. It may be concluded that the administration of primary education during the period dealt with in this paper was centralized and dependent on decisions issued by central government. Secondary education, for several reasons, was limited to the upper classes since National Schools were initially only available in the capital cities of each province. Act 1420 took on the modern perspective of «comprehensive education: moral, intellectual and physical education» and several clauses mentioned physical education for children. Among the fundamental academic requirements for compulsory education in this Act gymnastics and military exercises and march-pasts were included for boys; it also established that daily lessons at school should alternate with breaks and physical and singing exercises in order to ensure the effort of school work was not detrimental to general health provisions.

It may be said that the inclusion of physical education in school curricula was the result of three factors: firstly, the influence of the illustrated and republican pedagogic discourse inherited from the French Revolution, which claimed that the advancement of the nation depended on educating the people and that such education should include intellectual, moral and physical aspects; secondly, the influence of an ever growing military discourse from influential members of the leadership, which warned against possible border conflicts with Chile and demanded healthy soldiers educated from childhood to assist in the defense of the nation [17] and finally, claims by hygienists and eugenicists. Specifically, hygienists prescribed physical exercises as a prophylactic practice in order to counteract the urban problems of the moment; hygiene problems and TB epidemics were devastating the city of Buenos Aires. Eugenicists discussed and developed recommendations for mothers and children with the aim of achieving a strong, healthy national «race», from the crossing of Creole and European populations. Physical education was included among the means of achieving such good health.

"Rational physical education may make a significant contribution to this objective as it is already provided in the sport camps and gymnasiums of our cosmopolitan schools, making an encouraging impact on pupils of varied origins by developing such basic social attitudes such as solidarity, respect for the law and a commitment to collective efforts [...]. The constant presence of diverse social classes and diverse ethnic origins in the common struggle and in both government and employment, reinforced by a rational physical culture, will necessarily contribute to strengthening social classes and unifying sentiments and ideas in the general environment of Argentina where they are developing" [18].

French primary school (from 6 to 12 or 13 years of age and very rapidly extended thereafter to commence at age 3 and continue to 12 or 13 years) became free, compulsory and secular. However, because of the particular prior context, in other words the defeat of France in the war with Prussia and the occupation of Alsace and Lorraine with the very heavy financial and psychological tribute being paid by France, physical education in schools had a strong military bias. From 1882 until 1892, School Battalions [19] were the model for physical education for boys. This model was also adopted in Argentina, but many years later and for other reasons. In France the logic was that preparations should be made to take revenge against Prussia. However, school was also compulsory for girls too, but girls did not take part in the School Battalions. In rural France it was also the case that many children only attended school sporadically since the need to assist in reaping, grape harvesting, sewing and silage making etc. dictated seasonal priorities.

School was founded on a transmission model and in 1887 instruction was already capable of being programmed and this led to the development of a relatively top-down, disciplined education, the outcome of a combination of ecclesiastical preaching and the military model. 
Table 1. Comparative table between institutionalization of education \& physical education in Argentina \& France.

\begin{tabular}{|l|c|c|}
\hline Population & Argentina & France \\
\hline In 1880 & 1.8 millions & 39 millions \\
\hline $1880-1884$ & Common Education Law compulsory from 6-14 years old. & Primary school compulsory from 6 to 12-13 years old. \\
\hline School population & 33,759 & 3.4 millions \\
\hline $\begin{array}{c}\text { Bodily education } \\
\text { Different physical practices coexisted: gymnastic exercises, } \\
\text { military exercises and games }\end{array}$ & $\begin{array}{c}\text { Military gymnastics designed by Francisco Amoros, Georges } \\
\text { Demenij rational gymnastics and Games }\end{array}$ \\
\hline
\end{tabular}

There were a number of similarities and differences between Argentina and France at that time (Table 1). Strangely, in France, School Battalions were abandoned shortly before World War I yet the school context itself had hardly changed. The only significant change occurred with the creation through the Goblet Laws in 1886 of a higher primary school system which was extended to a small number of children selected from among the most capable. This system was still quite distinct from the secondary school system in towns that provided for the bourgeoisie and the aristocracy. In physical education many changes in content occurred under the joint influence of Philippe Tissié and Georges Demenij, as well as Paschal Grousset (alias Philippe Daryl). Baron Pierre Frédy de Coubertin tried but failed to get sport included in the school curriculum. Sport continued to be excluded from school curricula until World War II [20].

In France major institutional changes in schooling occurred through the Official Instructions of 1923 amending the proposed teaching methods by promoting active educational methods. The E.P.S. Instructions of 1937 and 1938 clearly promoted "The New School".

\section{PHYSICAL EDUCATION IN OFFICIAL TEXTS IN FRANCE AND ARGENTINA}

In France, ideas on physical education changed considerably between 1880 and 1940 [21]. In 1880, the approach to physical education was dominated by the Joinville military school. Yet it can be said that, from 1891 with the creation of the Station Physiologique du Parc des Princes (1884) and the Paris Advanced Course (Cours Supérieur de la ville de Paris) $(1884,1903)$ intended for school teachers from the department of La Seine and initiated by Georges Demenij (1850-1917), "complete, rounded and continuous movement" inspired by the Swedish method that he later called The French School (L'Ecole française an eponymous book published in 1909) that included energetic physiology replacing mechanical and military methods, although the active part of sessions might include some military exercises. However, the teaching methods seemed little changed; the transmission method was still in force.

In 1908, the Manual of Gymnastic Exercises and School Games (Manuel d'exercices Gymnastiques et de jeux scolaires) was the high point in the domination of Demenij's ideas. Subsequently, his influence declined, firstly in favor of Philippe Tissié (1852-1935) and then, after the 1913 conference, of Georges Hébert. The latter was to have a longterm influence in the domain of French physical education since the Official Instructions of 1959 still included his Natural Method in the practices available to pupils.

In January 1910, school manuals that until then had been the responsibility of Public Instruction (and Religion prior to the law of 9 December 1905), were replaced by General Rules enacted and issued under the authority of the War Ministry. Thus, the field of physical education was again dominated by the military, initially using the neoSwedish method advocated by Philipppe Tissié and then, following the Paris Conference of 1913, largely influenced by Georges Hébert's Natural Method (starting from 1909 and drawing in part from the contribution of Amoros). The Manuel d'exercices gymnastiques et de jeux scolaires of 1891 primarily promoted "the balance of physiological functions" [22]. Specifically, it clearly says: “The purpose of gymnastics is to perfect man's physique. It is 'the education of movement'; it is neither the exaggerated search for muscular strength nor the excessive ability to overcome exceptional difficulties but is one of the necessary conditions for the harmony of the human being" [23].

The Juvenal maxim mens sana in corpore sano [24] applies to the practice of school exercises that respect certain values: firstly harmony, meaning overall balance as well as and most importantly, a form of median practice with the logic of neither too much nor too little, as has already been demonstrated [25]. The text also suggests a multitude of exercises and games aimed at developing the Entire Man (an integrated education initiated under the Enlightenment). This is a reference to the term "harmony" in the above quotation. It provides the eclectic contents that Demenij subsequently called The French Method.

Official texts were organized on this basis up until the nineteen-fifties and sixties, but the system of values and practices was gradually modified. The Manuel d'exercices gymnastiques et de jeux scolaires of 1908 gives the 1891 provisions: 
"The purpose of physical education is to perfect and further improve man (...). Well managed, it maintains good health, fosters the normal development of the child, increases the physical and moral energy of the adult, maintains this energy into old age, engenders dexterity and strengthens character and determination" [22].

The basis is the achievement of a sort of harmonious balance in man, yet a second value system is apparent with the emergence of "energy" (physiological energy) as a central element in physical exercises. Furthermore, this definition is very different from that of 1891. Through the driving force of Demenij and the Emile Loubet Commission it is eclectic both in terms of practices and in values. It also promotes integrated education and group unity:

"The mental effect of the exercise is obtained by demanding personal effort. Bold exercises bring determination and virile qualities into play. Directing the activity towards a noble, heightened goal provides and strengthens ethical values. The moral effect is increased (...) by performing exercises collectively (...), as the necessity and duty for each participant to make their efforts conform and to submit their will to the common goal greatly develops a sense of discipline, camaraderie, solidarity and even of abnegation and sacrifice" [26].

An axiological and practical eclecticism flows through the text as well as the idea of training men for combat and self sacrifice for the homeland. The Physical Education Regulations mentioned above, were published by the War Ministry on $21^{\text {st }}$ January 1910, and embodied the same principles. They reveal a contradiction between the ideas that: "The purpose of physical education is the development and maintenance of the individual, compared with the achievement of a perfect performance" [27]. Above all it was designed for the greatest number and to include the weakest, yet at the same time had the objective of developing a few elite subjects by making use of: "selected gymnastics designed to increase the physical robustness of an elite [28] prepared to renounce group solidarity". The purpose of these gymnastics was to "awaken self respect". The document was of course, as eclectic in the exercises promoted as its predecessors, although a little more cognizant of the Swedish method through the driving force of Tissié.

Draft Regulations on General Physical Education. The French Method. (Projet de règlement général d'éducation physique. Méthode Française.) These regulations were published in four volumes (1919-1923), dominated by the Hébert method in volume I, which was intended for infants with a physical education concept based on achieving the general balance of the child in addition to eclecticism and an integrated education. "Purpose: to develop the child's normal physical faculties at the same time as their mental faculties [...]. Normal development ensures health, vivacity, mental balance and the sturdiness of the child; these exercises provide for the well-being of their mental and intellectual qualities" [29].

However, for advanced physical education in volume III, the intention was to seek: "The achievement of an allround athlete, endowed with qualities of strength, stamina, speed and dexterity" [30]. It also had to "develop the taste for and the habit of sports and athletic effort" [30].

In other words, the texts were always eclectic and from 1919 onward referred to the French Method, meaning a method that reinforced the national spirit and behavior yet incorporated other methods developed and advocated elsewhere. The focus was initially on the «Demenij method» then the «Hébert method». In both instances these methods were referred to as La méthode francaise. Similarly, this approach is found in Argentina with El sistema Argentino promoted by Romero Brest.

In Argentina during the early period after the enactment of Act no 1420, local schoolteachers and a few foreign teachers taught gymnastics with the primary objective of muscular development. The richest pedagogic experiences occurred in small groups in the various communities that had settled in the country. The programs included gymnastic exercises such as jumps, circumduction and races, games, and military exercises - alignment and marching. The proposed programs are mentioned in several articles and official recommendations without any didactic discussion and without comparing their relative benefits. In general, they sought uniformity with a high proportion of rigid exercises evidently taken from the military field [31]. This was not only due to the lack of institutions for training physical education instructors (courses of physical exercise for teachers were organized subsequently by Enrique Romero Brest in 1901), but also because once a military education had been declared compulsory in 1895 in all Secondary and Normal Schools (teacher training colleges dependent on the Ministry of Public Education), army officers, gymnastics and military education instructors were appointed to teach in provincial schools.

Later, given the political intention of the Act, the education authorities oriented the tasks of educators, inspectors and teachers towards the search and selection of more appropriate methods for educating the population. In the physical education field, this process took approximately twenty years, during which the Argentine authorities looked towards 
Europe - especially France, Germany, England and Sweden in their search for models.

In 1889, Dr. Luis Belaustegui, minister of public education, ordered the reorganization of physical education in National Schools. The reform stemmed from a ruling submitted by the general inspector of secondary education, Professor Pablo Pizzurno, replacing military exercises with a scientifically oriented program. Dr. Enrique Romero Brest played a fundamental part in drawing up this new program. Born in Corrientes in north-eastern Argentina, Romero Brest attended the province's National School and his physical education teacher was the English professor Thomas Reeves, who had introduced outdoor games and sports- football and track \& field - to schools in Argentina) [32]. Two years later, Romero Brest submitted his thesis for a Medical Doctorate which was accorded by the University of Buenos Aires.

In 1905 the executive authority presented a "Program for secondary schools and Normal Schools" to the Argentine Congress. Integrating the program was preceded by several decrees, which established the "normal theoretic and practical course of physical exercises addressed to teachers" in the three Normal Schools in the capital. That course was delivered by Romero Brest himself. This course of studies, which established the Argentine System as the official method [33] for school teaching and was intended to cover the whole population since physical education would be available in all primary schools once instructors in Normal Schools had qualified. In order to justify the value of his system, Romero Brest said:

"Of course, the system is a response to the social view point, to Argentina's national needs. These are determined by ethnic factors that are characteristic of developing a nationality in our country. The ultimate goal is the perfection of the race, covering both the physical aspect and aptitude for the social cohesion that drives the true energy of a people. Therefore, it attempts to educate the masses on solidarity, respect for the law, respect for one's own rights and a feeling of love for one's country. This starts by honoring the group in the sports struggles at school and continues later in the social struggle for civic-mindedness" [34].

Between 1884 and 1929 several plans and programs were created for primary schools, all of them arising from the intention to adjust the basic education established by legislation to the needs and possibilities of the various situations throughout the country (schools in the capital city, schools in rural areas, adult schools in national territories and colonies, aboriginal schools, frontier schools, etc.). In all of them, physical education was a school subject (sometimes called gymnastics, military exercises and calisthenics, or physical exercises). In all these programs - and despite to those that opposed Romero Brest's ideas - it may be said that the Argentine System was the prevailing method used. This system included methodized gymnastics and non-violent, pedagogic games. It expressly excluded field $\&$ track and competitive and spectacular sports. Any exercise that was harmful, violent, unaesthetic, useless, or dangerous or that had dubious effects was formally rejected.

"Harmful exercises affect health, aesthetics and the subject's education. Violent exercises are those that do not respect the physiological laws that rule the organic functions. They may affect blood circulation, breathing, musclebuilding, etc. [...] and may be dangerous because they entail hazards if performed incorrectly, or because of the intrinsic nature of the exercise itself" [35].

Later, merry-go-rounds and outdoor excursions were added. These definitions and qualifications appear repeatedly in work by Romero Brest and his followers, as well as in El monitor de la Educación Común, the official publication of the National Education Council. Something similar applied at secondary school level. Not until 1936 in primary schools, and 1941 in secondary schools, were new plans and programs approved that introduced nationwide changes in the subject. In primary schools, the Program by Subjects contains some of the New School ideas on movement which were not reflected in the specific recommendations for school physical education.

"The cultivation of capabilities for living a healthy spiritual and physical life - from the point of view of primary education objectives - shall be conducted through regular practice and appropriate study [...] and, on the other hand, through acts and modalities that ensure esthetic enjoyment and pleasure in living. It is to this aspect of education that practical activities of a healthy, aesthetic and amusing nature respond; they are included in the programs and they are attributed the importance that a simple observation of its order of presentation infers [...]

The development of the pupil's physical strength during normal bodily growth entails a school objective of unquestionable importance [...]; it is the school's vital responsibility then, to ensure the child a hygienic, joyful and healthy life, [...]. [At school], the child's physical development will benefit by, and be conducted through, physical exercise, children's games, adequate ventilation and lighting in classrooms and playgrounds, and other activities and 
practices that tend to contribute to the growth and health of the child's organism and that transmit to pupils permanent and rooted practices and habits of tidiness and good hygiene" [36].

In 1941 and 1942, Plans were passed for secondary level National schools, Normal Schools (teacher training establishments) and Commercial Schools. These plans incorporated sports - not as physical exercise but as agonistic, competitive games - as part of physical education at school. At this point sports became fully accepted as a school subject. Their inclusion cannot be understood solely as a result of non-school factors - such as the expansion of sports practice to new social sectors or by interest in it being roused through the press and later through radio. The pressure solely of sport instructors within the physical education field was not the only factor either. At this juncture, it was considered that sports added other benefits to the education of the human body. Besides the dynamics shared with games and their effect on energetic processes (this supplementary argument secured the position of gymnastics), sports have other additional virtues. Freedom of movement (as reflected in the development of a game, and in contrast to the static nature of gymnastics or a demonstration of calisthenics) and the individual initiative that emerges from different situations in a game together with the pleasure that comes from playful competitive activities (which allow effort to be sustained without apparent pain), combined with team work, promised new benefits in favor of social education and patriotism.

"In this program, games and sports have a fundamental importance. [...] The inclusion of sports in the school program is explained by the need to perform natural activities that interest students. [...] Sports competitions aim to stimulate the students' interest in healthy physical education practices; since they provide happiness, they teach students to pursue high ideals [...] by creating social awareness, cooperation and the spirit of community" [37].

In 1938, insofar as the province of Buenos Aires was concerned, Horacio Levene (Director of Army Gymnastics and Fencing) designed a New (Unique) Method, which reintroduced the military component into school physical education to include, marching, positioning and exercises with weapons: it replaced the Argentine System.

"Section 1. The lesson plans and programs created by the General Office of Physical Education and Culture set forth in the book 'Rules and lessons for methodized gymnastics and games' shall be hereby approved [...]

Section 2. The General Office of Physical Education and Culture shall indicate the weapons to be used in the instruction of shooting, and shall draft the corresponding instructions. [...]

It is hereby recommended to) Exhort the maintenance of the position of Attention when physiological reasons recommend it, and to keep order and aesthetics, which bring great pedagogic satisfaction [...]

In the Attention position, heels shall be in line and together; toes shall be naturally separated; legs stretched without effort; the torso shall be erect with the chest lifted and arched and shoulders square; eyes to the front; arms shall touch the body with the elbows slightly bent; hands shall be extended with the fingers touching the thighs" [38].

The New Method was included in Governor Manuel Fresco's education policies and vision for physical culture. Governor Fresco was a conservative politician with fascist ideas who admired Mussolini and feared communism would advance, imported by new Spanish immigrants arriving in Argentina after the Republican defeat in the Spanish civil war. As a result of the antagonism of the most concerned educationalist faction, the Argentine System was revoked by government resolution number 19 on 6 March 1939 [39]. The free movements and games of the Argentine System had only a minor place in the Unique Method. Initially, Levene relegated them in favor of a methodized and disciplined gymnastic exercises; later, he reserved them for younger age groups in primary school and for times when pupils showed signs of apathy or indifference.

"In fact, children undertake these 'natural' gymnastics excessively and without control, which causes joy and pleasure in streets and squares with no assessment of the consequences of these activities; running, jumping, climbing. Freedom of movement, freedom in playing and freedom in learning flow immeasurably everywhere, so it would be fairer to call it a license. True methodized gymnastic exercises, not those which are quoted theoretically, but that which are taught with effective comprehension and conscience, force order of movement thus favoring development, corrects deviations, and educates the will; these are basic factors to develop good health and define the character" [40].

\section{IDEAS DEBATED IN BOTH COUNTRIES}

During the first years of the twentieth century, Dr. Enrique Romero Brest designed the "Argentine System of Physical Education" from studying and comparing the methods existing in continental Europe. His approach attempted to settle the debate between rational physical education (scientific, physiologic) versus empirical gymnastics, and, above all, to foster the advance of military gymnastics. 
In his thesis entitled Physical exercise at school (from a health and hygiene standpoint), he developed the political, social and health reasons to justify why scientific or methodized gymnastics - with foundations in anatomy, physiology and psychology - should be taught in schools. In his thesis he also proved and explained the intellectual process and mentions European authors in support of his ideas. The statements he formulated regarding the need for physical education for individual and social survival, the functioning of the organism, brain activity and energy consumption during work, were constantly asserted with references to European physicians, physiologists and even philosophers (Mosso, Lagrange, Tissié, Le Blond, Arnould, Bouchard, Bain, Luys, Labit y Polin and Spencer among others.) In the more specific field of methods, he mentioned Demenij, Marey and Ling. At this point it should be noted that some Argentine physicians (who had written theses on Social and school hygiene, The Influence of customs on health, Diets or on Medicine and Morals, for example) allotted whole chapters to physical education or exercise, and accounted for similar theoretic influences (names like Pinel, Esquirol, Cabanis, Ribot may be added to the list, in order to explain how the senses, will, character and intelligence function). It should also be pointed out that these same theoretical influences, for example Lagrange's ideas, would also be apparent in the methods described by the members of the School of Gymnastics and Fencing of the [Argentine] Army later in the nineteenth thirties.

In 1905, having been appointed Inspector of Physical Education for the National Council of Education, Romero Brest took responsibility for disseminating ideas among teachers, directors and inspectors of the public educational system, of physical education based on positivism - knowledge derived from sensory experience — anatomy, psychology and particularly, physiology. In several books and articles he revealed the main concepts of a system that would legitimize rational physical education as a school subject and the most appropriate method for schools - later called the Argentine System). He began by comparing education methods, analyzing European gymnastic systems and highlighting that, just as other peoples had created or transformed their physical education systems, there was a need to do the same in Argentina as a consequence not only of "scientific curiosity", but also for the purpose of avoiding "absorbing" European systems of exercise. He describes his reform as social, since his aim was to modify the people and the race:

"Based on these ideas, I have rejected using the French method of Physical Education because it is anti-physiology; the German method, because it still exhibits a military nature through its origins; the English method, because it does not fully adapt to gradation and its application in our schools would be difficult due to local conditions; and the Swedish method because - despite its eminent scientific basis - it has an incomplete psychological aspect, as its strict method demands specialized staff, suitable local facilities and, maybe, racial qualities that we do not have" [41].

Despite his rejection of European methods, his recommended method was an eclectic summary of the exercises and activities drawn from each of them. Romero Brest saw that confirmation of its success as a social regeneration technique would be its extension to the popular masses and it was for that reason that he put the focus on the role of school. He proposed methodical, regular and rational physical education oriented to promote four factors. "The immediate and practical object of rational physical education has to be the harmonious, intense cultivation and development of all individual aptitudes under four essential headings: health, aesthetics, value to economic productivity, and good morals" [42].

Approval of the Argentine System as the official method in plans and programs and its permanence through to the nineteenth thirties, must not be regarded as the result of an agreement among all parties interested in physical education; it was a product of a combination of Romero Brest's academic and political weight, the importance of the Higher Institute of Physical Education he created and directed (until he retired in 1931), the Laboratory of Physiology he ran at the Institute, the Association of Professors of Physical Education (over which he presided) and the support of eminent teachers, civil servants and intellectuals. It has to be acknowledged that throughout the whole period there were dissenting voices regarding his proposals and his personality, but until the nineteenth thirties they did not manage to change the relationship between the forces that kept him in charge of physical education in Argentina.

Needless to say, the conflicts and tensions arising from the military approach in the teaching of physical exercises were not exclusive to Argentina, nor were they initiated at the end of the nineteenth century. As Mosso indicate [43], military gymnastics extended throughout the nineteenth century supported by nationalist ideals and by the incorporation of compulsory military service, making the fitness of the recruit and the high school male student a subject of national interest.

In Argentina, this process developed during the last two decades of the nineteenth century [44]. At that time new institutions were being created fostering these military initiatives, such as the Gymnastics and Fencing Cub of Buenos 
Aires (GEBA) in 1880, the Army's School of Gymnastics and Fencing in 1897, the Argentine Sports Society in 1899 , and the General Office of Shooting and Gymnastics in 1905, which reported to the Ministry of War. Leading figures such as Eugenio Pini, Baron Antonio de Marchi, Escipion A. Ferreto, Clifton Goldney, Eduardo Munilla, Samuel Borghelli, Adolfo Arana, Horacio Lavene and Arsenio Thamier emerged from or were members of these institutions and strongly opposed Enrique Romero Brest [45].

As Scharagrodsky pointed out, the attempts to militarize school and the human body conducted since the end of the nineteenth century were resisted by eminent teachers (Alfredo Ferreira, José Benjamín Zubiaur, Pablo Pizzurno, Santiago Fitz Simon, etc.), by state employees (Ponciano Vivanco, Luis Beláustegui, Felipe Guasch Leguizamón, Juan Beltrán, Enrique de Vedia, Manuel Derqui, etc.), by sectors of the teaching community, by the National Council of Education and by certain members of the scientific community represented by physicians like Enrique Romero Brest. And although the Argentine System held its position in the public education system until the nineteenth thirties despite attempts on several occasions by the sector representing the military perspective of physical education and supported by sportsmen who opposed Romero Brest to re-install military exercises in school practices - including in the form of School Battalions.

It should be mentioned that in Argentina School Battalions had not originated in schools, nor were they organized by civilian teachers. Their creation was at the initiative of the Sports Society - a sports association very close to the Army and its department of gymnastics and fencing. The first appearance of students with military positions, activities and organization took place in the years prior to the celebration in 1910 of the Centenary of the May Revolution [46]. Subsequently, in the years that followed the Centenary (between 1911 and 1914), these same groups tried unsuccessfully to introduce such exercises in school curricula in the province of Buenos Aires and in schools that fell under the responsibility of the National Council of Education. One of the many ways in which the followers of the Argentine System made public their concerns regarding the military approach was via the Journal of Physical Education [47].

"A serious threat to physical education.

School battalions revived by the Olympic Games Commission from the fair oblivion where they've lain dormant for more than twenty years, have already started to bear fruit [...], [they are] harmful [...] for children's physical education. [...] We had foreseen what was about to happen and we understood that such military contests were only the prelude of an idea that wished to gradually take over the teaching of physical education and realign it under the Ministry of War, withdrawing it from its legitimate place within public education [...].

The time has come. Initially, there was an early attempt to introduce an unrealistic Bill in the House to allocate the direction, administration and techniques of physical culture to an independent association. In the sports field, this association had proved to have certain propaganda capacities but in the field of school techniques its advocates' total lack of scientific ability has been evident. [...] The second attempt was even more worrying since it was sponsored by the Ministry of War. We don't doubt the department's good faith [...] but we can only strongly disagree with the criteria guiding such good faith, and so we shall analyze it.

The Army's General Office of Shooting and Gymnastics has requested the Ministry of Public Education to make military gymnastics compulsory at every level of National and Normal Schools, and that its teaching is put in the charge of army leaders. [...] Clearly, the Ministry of War intends to invade public schools" [48].

During the nineteen-twenties, active members of the army as well as athletes became increasingly critical of the Argentine System. The considerations taken into account by these groups were somewhat similar to the issues raised by pragmatists, activists and "scholanovists" which gained ground in the overall didactic discussion while opposing "declining positivist intellectualism". In France, within this framework, members of the army became interested in the Natural Gymnastics established by George Hébert and even though the Army School of Gymnastics did not introduce the system, they used it to justify their disagreement with the physical education method of the Argentine System. Criticizing "artificial and methodized" exercises served as a cudgel challenging the Argentine System and expressing doubts about the training imparted in the Higher Institute of Physical Education in the official publication of the National Council of Education. The polemic seems to have gained ground in 1924 with the setting up of a commission to "advise the government on the most suitable physical education system, method and procedure". The formal decree emphasized the inadequacy of the Institute's training and the requirements of schools and the sports field and ordered the suspension of the first year of Physical Education in the Normal School. Students should be enrolled directly in the second and third years [49]. 
The commission formed comprised the Chief Inspector of secondary, higher and special teaching, a delegate of the National Council of Education, the director of the Higher Institute of Physical Education, a delegate of the National Ministry of Health and Hygiene, representatives of the Medical School of the Universities of Buenos Aires and La Plata, a representative of the Ministry of War, a representative of the Ministry of the Navy, and the director of physical exercise fields in the capital city "an expert on the subject". This organization was the outcome of the struggle by the teaching community to prevent the Commission from being monopolized by opponents. It successfully combined the viewpoints of the military sector, the sports sector and that of scientific physical education.

However, the Technical Commission issued a study in which the status quo seemed unchanged. The Commission prepared a Bill for a law organizing national physical education under three distinct headings: a) School physical education; b) Sport and physical education; c) Physical education based on and complementing military education. It established that for bodily education under each of these headings a different type of exercise or practice was needed: methodical physiological and healthful physical exercises in school physical education; post school rational and athletic sports exercises in sports associations; and physical exercises of a practical, professional and military nature together with any other specializations in the army [50]. This Bill was never discussed in Congress.

To terminate the explanation of ideas on physical education that were topical in Argentina, we should mention that besides the technical (or scientific) reasons that opposed physicians and teachers and members of the army and athletes, the main differences with France lay in the concept of citizenship, order and authority that derived from each position. Both groups agreed on the benefits of physical exercise during childhood and that school was the best environment for its systematic development, but they strongly disagreed on the method, the type of discipline and the profile of those who were professionally capable of teaching it. The military maintained that children should get used to doing military exercises to strengthen their bodies and discipline their spirits and that the best way to achieve this was through the presence of army agents in schools. Teachers and physicians were convinced that the children's physical education should be achieved by scientific methods (based on knowledge of anatomy, physiology and psychology) and that teachers should be trained to do this. They reinforced their ideas by pointing out that military gymnastics, based on strength and violent movements, might be useful in preparing adult soldiers, however in schools not only was it counterproductive for a child's physical health, but also for their civic education. They argued that vertical-type military discipline was not the most appropriate way to educate future citizens of the nation; instead, discipline should be based on republican reasoning and moral values and not on acceptance of hierarchical authority [51].

A number of the writers whose opinions were discussed in Argentina and who were key players there were repudiated in France. Their ideas and practices were even referred to at the time as a "war of methods", they were so thoroughly discussed and debated. The most serious controversy was between the communard Paschal Grousset (Philippe Daryl, 1844-1909), and an aristocrat from Versailles, Baron Pierre Frédy de Coubertin (1863-1937), the argument being specifically about the values upon which physical activity should be based. Opposed to sport, Grousset attached a great deal of importance to traditional French games but as far as he was concerned the basis was not physiological (as it was for Lagrange and Demenij), but political. For him, games were a physical activity for the people and not the sports enjoyed by the aristocracy which he abhorred. Grousset was not a physician but a politician - at the age of 27 he was the Delegate for External Affairs for the insurrectional Paris Commune. For him, sport was an aristocrat's activity that had no merit for the masses and the proletariat. Quite the contrary, he considered that the values imbued by sport were extremely detrimental for equality and fraternity as they provided an individualist, elitist exercise model. However, other conflicts arose.

Philippe Tissié, a physician who qualified in 1887, was influenced by traditional and mechanical forms of exercise. Although he published the Revue des jeux scolaires from 1890, it was the Swedish gestural form that he most favored (a demonstration of the Nomadic nature of the theory and bodily technique). The Lendits that he helped to establish in 1891 were Swedish gymnastic exercises undertaken by a group in a public square or in a stadium. This preference brought him into violent opposition with Demenij for scientific reasons. The latter reproached him for using a mechanical and not an energetic base. However, although he advocated cycling or races on foot within the Girondine Physical Education League, his assignment in Sweden between 1898 and 1905 convinced him that the Swedish method was ideal for school physical education in France. His prodigious classes at the Pau Teacher's Training College for Women (Ecole Normale de Jeunes Filles) from 1903 to 1914, the positive results and the high praise of the head mistress, reinforced his commitment to applying the Swedish method in primary school: "It has been claimed that Swedish gymnastics is boring. Let us be frank. Any school subject can become uninteresting and tedious depending on the pupil's taste and aptitude, but it is above all the way the subject is taught that determines how a discipline is 
judged." [52]

Demenij subscribed to quite another argument. He was an enthusiastic rationalist close to Muybridge, Marey and Mosso. He had a major disagreement with Tissié on the bodily techniques to be used for organizing a rational, energetic gymnastics school:

"Protagonists of the Swedish method sometimes imagine they take science fully into account because their methods comprise movement of the whole human body, but these movements are pernicious, badly executed if they are performed without method and suffocated by a host of others that destroy their useful effect; the system is vicious and [esteem for] the gradation of the exercises can only be misplaced since it is based on the exterior form of the movement and not on the useful effects to be produced" [53].

This comment from the preface to Physical Education in Sweden (L'Education physique en suède) by Colonel Lefébure is signed Demenij [54], although he was not, as has been seen, a fervent partisan of the method. By contrast with Tissié, he was not fully convinced of this need after his study trip to Sweden with Lagrange in January 1890 [55], a trip for which he had solicited support from the Minister of Public Instruction for the Marey Commission, The critique of "certain protagonists of the Swedish method" targeted Tissié, whose scientific arguments are questioned in a large number of articles, specifically in La Revue scientifique at the very end of the nineteenth century. It was thus both a position of support and of defiance that motivated the rhetoric of the passage. The spiritual son of Auguste Comte and Ernest Renan, Tissié convinced the positivist Demenij that he did not accept that only military gymnastics and the entertainment tradition would enable the quality of a physical education method to be decided:

"The desire to make everyone an athlete must be abandoned and [...] wisdom also advises leaving circus folk to perform complicated exercises [...]. The Swedes, the Swiss, the Germans [...], our monitors at the Joinville-le-Pont School, can compete with the most magnificent [human] specimens from the ancient past, but such examples are unfortunately exceptions [...], if we wish to get closer to [forming] the specimens that are given to us as ideal we must make a sensible choice of gymnastic subjects" [56].

This can be seen as a critique of any dogmatic position and above all of any single method, whether this be the Swedish, sports, German or French military. Demenij suggests a new eclecticism that sacrifices tradition and adopts the perspective of progress and modernity. After his visit to Sweden, Demenij's opinion is decided (and perhaps it was already decided following his contacts with Commander Black, the manager of Swedish gymnasts in France or from alliances made within the Marey Commission, created on 18 October 1887 and for which Demenij was one of the rapporteurs, with Marey, Lagrange, etc.). "However, progress in physical education is impossible if we are restricted to obsequiously respecting and imitating the past. [...] We do not see the imposed right of the laws of nature of which we are the result. If we wish to produce long-term work our concern must be to know nature's laws and so be better able to submit to them" [57].

Known laws on which Swedish gymnastics are based date from De Motu animalium, Borelli, 1680: the point of support, the center of gravity and the three types of lever are the basis of Galilean mechanics applied to the body [58]. However, Demenij discovered the work of Hirn, Chauveau and Marey and could not accept this solely mechanical basis. On the contrary, a bio-energetic base seemed to him to correspond with the "laws of nature". These at least were the recent Nomad scientific concepts that he adopted in the perspective of advancing science: "We thus arrive, by elimination, at conserving as material for physical education programs, the general means that increase man's output, considered as the source of mechanical work [...] the purpose of education [...] is an economic purpose having as a consequence increased output from human activity" [59].

This point of view is found in the Manual of 1891, but consensus forced mechanistic viewpoints to continue being mentioned in it as well as the military approach. This was very clearly expressed in the conclusions of the report to the minister that appeared in 1892 following a study trip, with the title: Physical Education in Sweden:

“An entire physical education system would consist of: $1^{\circ}$ Taking from the English their hygiene, their open air recreations, without however taking up the competitions that are intended for an elite minority; $2^{\circ}$ Taking from the Swedish their pedagogic and esthetic gymnastics; and $3^{\circ}$ Retaining our gymnastics for military application [...] such as is carried out at the Joinville-le-Pont School" [60].

Demenij, through Nomad ideas, sought to bring out the eclecticism that he called the French Method. It was through this and not his Swedish nonconformism that he crossed swords with Tissié: "I have spent some time visiting the main establishments from Lund to Lullen [...]. I have thus become convinced of the superiority of a strong military teaching 
method still little known in France yet that has achieved magnificent results in Scandinavia" [61].

Tissié actually had good reason to support the Swedish method. He had in no way benefitted from the training in bioenergy that Demenij had received at the Sorbonne (he seemed to know little about the subject prior to 1919). There was also a need for the two men to be differentiated in competitive terms. This was clearly demonstrated from the structure of the Higher Commission on Physical Education and Youth (Commission Supérieure de l'Education physique de la Jeunesse) on 14 May 1898, since, while the sub-commission on games was entrusted to Callot (scarcely known in the field), gymnastics with apparatus was managed by the two protagonists. Demenij and Tissié could therefore see that they were in competition as well as in conflict. Their positions became more clearly stratified at the time of the first International Conference on Physical Education in Paris, linked to the Universal Exhibition from 30 August to 6 September 1900. But the institutional fact that was to change everything and of which Philippe Tissié only became aware in 1901 when he wrote: "an understanding has been achieved [...] the work of the International Congress of 1900 can be summed up in two words: Union and Organization", [62] so it was not a neutral individual in the conflict that became the delegate for France in the organization of the 1902 congress, but Demenij [63].

Similarly, in 1903, it was not Tissié who was named the head of the advanced classes but Demenij. This event signed the provisional defeat of Tissié in the "war of methods". Demenij had become the greater authority and with that his French Method. He scarcely relaxed his hold (the exception being the Joinville regulations of 1910 where Tissié was consulted) until the 1913 conference where Tissié was excluded. Tissié's criticisms consequently became even more acerbic concerning Demenij's French Method: “But his first set of regulations of 22 October 1902 is so eclectically defective that it gives poor results. Demenij, who drafted them, has not understood Ling's principles" [64].

Finally, on 13 February 1903 in an article entitled: Physical Education (concerning two books) (L'éducation physique (à propos de deux livres) that appeared in the Revue Scientifique Tissié showered praise on Physical Education in Sweden by Colonel Lefebure and assassinated The Scientific Basis of Physical Education by Demenij in 1902. He repeated this exploit on 24 June 1903, in an article entitled The Evolution of Physical Education in France and Belgium (concerning two educational methods) (L'Evolution de l'éducation physique en France et en Belgique (A propos de deux méthodes d'éducation). He again criticized the book published by Demenij, J. Philippe and G. Racine: Advanced Classes in Physical Education (Cours supérieur d'Education Physique) that he compared with a new book by Colonel Lefebure entitled: Method of Educational Gymnastics (Méthode de gymnastics éducative):

"Mr. Demenij [...] and Captain Lefébure have each published a book. That of Mr. Demenij concerns theory, that of Mr. Lefébure comprises an account of things well observed in Sweden [...] The same two authors have now published two new works [...] we therefore possess exact data on physical education in France using the Swedish method amended by Mr. Demenij, and in Belgium using the same method but retaining all its purity by Mr. Lefébure [...] In all sincerity, reading [Demenij's] Cours supérieur d'Education Physique disappointed me; reading [Lefèbre's] Méthode de gymnastique éducative satisfied me" [65].

For Tissié in any case: "Demenij, not having fully understood the precise value of the Swedish gymnastics method wanted to correct it because he found it 'monotonous through its lack of resources' [...] Mr. Demenij therefore designed a hybrid method that moreover gives no satisfaction to the critical spirit; Mr. Demenij is eclectic, the truth is not" [66].

Demenij, quoting Ling, in fact questions Swedish uniqueness when he says: "Even Ling's concept involves progress with the advances in the science on which it is based. Its disciples, on occasion too rigorous, do not accept the idea of this evolution and credit its system with being perfect and invariable. It is an exaggeration for which the good spirits are grateful" [67].

Tissié responded: "Mr. Demenij must correct his eclectic error" [68]. In any event, it is on the basis of this eclecticism (derived from Nomad theories) that Demenij was able to formulate a specific method recognized by the State itself. He accomplished this in Evolution of Physical Education. The French School (Evolution d'éducation physique. L'Ecole française), in 1909. This method was submitted to the French Biological Association on 11 June 1910 with the title: The importance of continuous, complete movement in direction and extent following curving trajectories on muscular development and education of nerve center coordination.

Yet other more consensual players took part in this war over methods, specifically targeting, as in Argentina, the definition of a national system, and based on Nomad ideas. Lagrange, who completed his medical doctorate in 1869 , devoted himself to the practice of athletics and research in the field of bodily physiology. He travelled Europe to study current methods. The conclusion he drew from his travels was that gymnastics built strictly on the Swedish model was 
of little interest and that what was really of significance was an attractive exercise. He emphasized therefore the value of games, fresh air and sport though he considered games as being for adolescents. Based on a bioenergetics conception of the body, he also refuted practices that were too tiring.

In 1892, Lagrange was a member of the Education Reform Commission. He contributed to The Manual of Physical Exercises and School Games (Manuel d'Exercises Physiques et de jeux scolaires) of 1908. He stated time without number that:

The human body compares, as a source of energy, with a machine that operates using heat. [...] The most perfect motors merely transform heat into movement [69].

Furthermore, in 1890 Lagrange published several papers with Baron de Coubertin and Georges de Saint-Clair in La Revue athlétique, particularly on the subject of adolescence. He took part in the Committee for the Propagation of Physical Exercises, forerunner to the sports federations and in 1889 the French Union of Athletic Sports (Union des Sociétés Françaises de Sports Athlétiques - U.S.F.S.A.), chaired by Jules Simon and set up in June 1888 on the initiative of the Baron. He was one of those involved in the development of the sports movement in France. Even those writers who were hostile to competitive sport, like Demenij and Hébert later on, quote The Physiology of Bodily Exercises (Physiologie des exercises du corps, 1888). The paper received the Vernois award accorded by the medical school. A report affirmed that: Dr. F. Lagrange has written an excellent paper on the physiology of bodily exercises from the dual point of view of science and practice [70].

There is a paradox in the fact that Lagrange took part not only in the Jules Simon Committee, but also in its institutional adversary: the National League for Physical Education (at the time known as the French League for Physical Education) created in October 1888 on the initiative of Paschal Grousset, who published that same year: Physical Renaissance (La Renaissance physique), a critique of English sports practice promoted by de Coubertin: Education in England (L'Education en Angleterre) and English Education in France (Education Anglaise en France).

The ideological proximity of Tissié and Grousset created conflict between him and de Coubertin. Tissié, in fact, organized the Lendits in Bordeaux and invited de Coubertin. However, while initial relations were good, the Baron soon became mistrustful of the Tissié/Grousset relationship:

"I would like to be enlightened on your relationship with the National League for Physical Education. [...] The lack of consideration for the founders of the League in relation to the Committee was strongly resented by Mr. Jules Simon and his colleagues; and if the Bordeaux Lendits are to be chaired by Mr. Paschal Grousset, a man I mistrust and with whom I wish to have no contact, I shall certainly refrain from appearing there" [71].

The close axiological link between Grousset and Tissié soon became a bigger issue. The last written exchange between Tissié and de Coubertin is evidence of this: "My dear Dr. Tissié, I am now, [...], asking you whether it is peace or war that you want between us. [...] I know, from your words and actions that you honor the Union by loathing it and you seek to compromise it [...] But above all reply clearly and do not give me a mild spray of holy water which I shall not believe" [72].

To which Tissié replied, taking up the religious reference: "My dear Friend, This is how I wish to address you until further informed - I detest the sprinkler too much to make use of it: do not fear receiving a mild spray of holy water from me" [72].

A political (patriotic) base bound Tissié and Grousset while everything put them in opposition to the Baron. When Tissié decided to break with de Coubertin, it was for these reasons and not, as with Demenij, on the basis of scientific arguments that he used to indicate his dislike of champions and preference for all school children. Tissié is no longer writing to a friend:

"Dear Commissar General, You really wanted to invite the Gironde League for Physical Education to take part in the Union of Athletic Sports Conference that will be opened and held in Paris [...]. I regret to inform you that the League finds itself unable to be represented at the Conference [...]. In fact, questions from amateurs and professionals as well as the revival of the Olympic Games do not directly interest the Gironde League as it is only involved in young people and children at school" [73].

These extracts provide clear evidence of the battle being fought in the heart of physical education over the definition of a National method. Tissié supported Sweden, de Coubertin England, Demenij bioenergetics and Grousset French games. Lagrange was the pivotal point in the sense that for him any exercise was good exercise if it made use of the 
energetic process and if it implied not leaving young people and children confined in the class room only. His ideas were also discussed when the National Method in Argentina was being drawn up, just as were those of Mosso, Demenij and Tissié. Again, these were Nomad ideas.

Yet in France the best known, highly reputed writer of the period (after the conference of 1913), was Navy Lieutenant Georges Hébert, acolyte of the natural method, giving great attention to the fundamental, energetic and natural form of exercise. In this, even though his method is built on ten activities: walking, running, climbing, lifting, carrying, moving on all fours, self defense and swimming [74], the essential for him was less a matter of the form of exercise taken than with activation of the human organism. In this respect, Hébert was very close to Lagrange and Demenij. What separated him from the former was the fact that Lagrange accepted English sport while Hébert, just like Grousset, Demenij and Tissié, considered it a "social scourge" [75] in that it engendered narcissism, egocentrism and elitism. Hébert explicitly cited Lagrange (he very rarely quoted authors) when it was a matter of determining the physiological basis for his method. Furthermore, he frequently used the concept of «fundamental» training, in other words, a concept based on energy as providing a basis for Virile and Moral Physical Education using the Natural Method (L'Education physique virile et morale par la méthode naturelle) [76]. Just like Demenij, he sought to establish a French Method based on the natural method. His stamp is apparent in every paper from 1913 onwards.

All these writers however, asked few questions on pedagogy in the strict sense. Lagrange thought that the game was good for a child. Demenij considered that pleasure would be found in conscientious work and Hébert simply stated that a child should find work joyous. For his part, Tissié favored the disciplined reproduction of simple gestures. It was very unusual for any of them to refer to a child's development. Girls, except in the case of Hébert, were practically unmentioned, and were even disparaged by de Coubertin.

\section{EUGENICS IN ARGENTINA AND FRANCE, AN EXAMPLE OF NOMAD THEORIES}

A very rich topic for understanding the current of ideas on educating the body throughout the period covered by this article is the scientific and social movement known as eugenics. At the time it was said that Science would lead to the improvement of the human race depending on its hereditary composition, through the preservation of purity and the reproduction of adequate human specimens, and by avoiding transmitting the legacy of unfit specimens [77].

As the social application of knowledge on inheritance developed to improve livestock production, these new social ideas and policies - initially applied in England - circulated along with other ideas in those nations which, since the mid- $19^{\text {th }}$ century, conformed to streamlined State models transiting from traditional forms of organization (with a central role accorded to religion, dogmatic ways of thinking and kinship-based organizations) to modern ones (secular, with rational ways of thinking and an organization based on a scientific approach). They would have a particular reception in the "newly independent nations" (such as those in Latin American) that were trying to reinforce or accelerate the modernization process by encouraging immigration of European origin.

From its beginnings in Europe, among public health specialists, eugenics was considered a minority, specialist perspective that reinforced the biological view of health as opposed to the environmental view held by most social reformers. At the same time it was not a single homogeneous movement. Currents could be found that favored human improvement through modification of the environment (social, cultural, and natural) and others would suggest such improvement could be achieved through avoiding procreation by people considered inappropriate (poor, alcoholic, mentally ill). Stepan identifies these currents under the heading "positive and negative eugenics" respectively.

To understand the impact and reception of eugenic ideas in Argentina, it should be remembered that towards the end of the 19th century this was one of the few countries in Latin America with a majority white population, since a large part of the native population had been exterminated and the black population was approximately $2 \%$ of the total. Legions of immigrants from Europe would settle in Argentina. In this context some of the earlier eugenic ideas began to be part of the political agenda apparent in the work of the physician Emilio Coni, one of those promoting the legislation for procreation control. Coni considered that such legislation would hasten the building of a modern progressive nation [77]. A number of political events facilitated the proliferation of ideas of control and racial hierarchy through positive eugenics [78]. The Residence Act (1902) and the Social Defense Act (1910) were passed with the aim of controlling immigration and identifying and expelling those foreigners whose ideology did not match the liberal discourse. Eugenics programs were developed more intensely between the 1920s and 1930s, when social issues (like disorganized population growth, groups of foreigners that did not mix with the indigenous population, social upheaval caused by unionized workers) began to worry the ruling classes. 
Although in Argentina there were supporters of negative eugenics who proposed sterilizing the "unfit" or preventing them from marrying, in the field of physical education the influence of a strong current in favor of positive eugenics is recognizable among the justifications that were given to support the compulsory teaching of this subject in schools. One of its promoters, who considered physical education as a modifying rational agent, affirmed:

"It is deduced from all this that the modification of the organic individual under the triple aspect, physical, moral and social, is a possible and normal fact of life, and therefore, that this discipline, in the hands of a conscious and scientific educator, is capable of producing fundamental facts of organic and functional modifications, as evidenced by the school influence everywhere. [...] The philosophical importance of these facts, their high value and transcendental meaning are undeniable [...] since their effects are not limited to the isolated physical individual but they extend indefinitely through races and time, profoundly influencing the social individual as well" [79].

The above quotation indicates the importance of the environmentalist perspective; however, the hereditary perspective also has its place among the purposes of physical education when focused on developing the fitness of girls in order for them to adequately fulfill their role as mothers. "It is the physical nature of women that calls for aid, since their entire life, regulated by public opinion, false prejudice, fashion, all sorts of considerations and their occupations, asks for help in order to fight against their natural weakness. It is women that must be strengthened so they have the necessary skills for the fulfillment of their duty, their high mission" [80].

During the same period or just a little earlier, generally in Europe and specifically in France, eugenics had a huge impact on gymnastics and physical education. However, in France the distinction must be drawn between positive and negative eugenics. For Galton (1822-1911) who was one of the first promoters of eugenics in Britain, it was essential to eliminate the weakest races and not mix the desirable lineage of the English upper class with that of lower social classes. In fact, for Galton, the degeneration of civilization is related to the mixing of social classes. Preservation of desirable lineage necessitates firstly preventing intermixing and if necessary eliminating disabled and inferior specimens. Such is negative eugenics.

In France at the end of the nineteenth century Baron Pierre Frédy de Coubertin held a eugenic point of view but he advocated positive rather than negative eugenics. In Gymnastique utilitaire, in 1905, he defended the position that some people are members of the superior race and others, the larger proportion, are members of inferior races. According to him black people would be unable to win any event in the Olympic Games because they were physically inferior; white people were superior. Physical education, gymnastics and sports were a way to make a selection and also to change genetic heritage in a single generation. For this reason some French authors including Demenij, Tissié and Hebert wanted women to take part in physical education activities. They thought that such activity would be good for the future of the French race.

Enrique Romero Brest was present at the Congress of Paris in 1913, benefiting from conferences given at the Sorbonne by Nobel Prizewinning speakers. Two such speakers, Alexis Carrel (Nobel Prize for Physiology and Medicine in 1912) and Charles Richet (Nobel Prize in 1913), were defending positive eugenics and advocating physical education for all. Like Galton they believed that the second industrial revolution resulted in degeneration of the European race and that sport and physical education should be used to prevent such degeneration for the greater number. Carrel (1873-1944) later wrote Man, the Unknown (L'Homme cet inconnu) in 1935, which argued in favor of eugenics. In the preface to the American edition in 1939 he wrote: "These royal gifts of science have burst like a thunderstorm upon us while we are too ignorant to use them wisely. And they may become highly destructive. [...] Europe and the United States are thus undergoing a qualitative as well as a quantitative deterioration. On the contrary, Asiatics and Africans such as the Russians, the Arabs, the Hindus, are increasing with marked rapidity. Never have the European races been in such great peril as they are today" [81] But following his early writing around 1912, he became a strong supporter of positive eugenics. We have also to remember that he was a member of Doriot's fascist party: The French Popular Party (Parti Populaire Français).

Charles Richet (1850-1935), author of an influential book on the subject of exercise: Animal Heat (La Chaleur animale) published in 1889, also held eugenic views that he elucidated in his 1930 work Physical Education Treatise (Traité d'Education Physique). In 1919 he wrote a paper entitled Human Selection (La Sélection humaine) where he said:

"When it is a matter of the yellow race, and even more so of the black race, in order to preserve and particularly to increase our mental abilities, it is not a question of conducting individual selection as for our white brethren but of specific selection by resolutely avoiding any mixing with inferior races. [...] Therefore an administration must carry out 
the 'elimination of inferior races' and then of all "abnormal persons" [82].

This is negative eugenics, but in the field of physical education in Europe and more precisely in France such theories were approved. It is known that a number of French authors are cited in Enrique Romero Brest's thesis at the beginning of the $20^{\text {th }}$ century in Argentina. For example, Philippe Tissié who made a very important contribution to the subject of physical education in France wrote a book entitled Physical Education and Race. Work, health, longevity, (L'Education physique et la race. Travail, santé, longévité) in 1919, which clearly advocates eugenics. So eugenics seems to be a Nomad theory traveling from England (Galton), then adopted in France (Carrel and Richet) in the field of physical education (Demenij, Tissié, de Coubertin, Lagrange and Hébert), reaching Argentina through the Congress of Paris in 1913 and in the person of Enrique Romero Brest among others.

\section{CHANGES IN TRAINING INSTITUTIONS AND DIPLOMAS IN FRANCE AND ARGENTINA}

In 1880 the only French training institution was the military and civil school of Joinville (created in 1851 by Napoleon Laisné) responsible for training military staff as gymnastics instructors holding the Aptitude Certificate for Teaching Gymnastics (Certificat d'Aptitude à l'Enseignement de la Gymnastique) which was created on $3^{\text {rd }}$ February 1869, following the Hillairet Report (1868). The latter described the pitiful state of gymnastics instruction in French schools by comparison with those in Prussia and Scandinavia.

In 1880, Demenij and others (Racine, Sandoz, Marey) founded the Circle of Rational Gymnastics, which published the Bulletin of the Rational Gymnastics Circle (Bulletin du Cercle de Gymnastique Rationnelle). The Circle taught infants and junior school teachers (Instituteurs) in the department of La Seine and in Paris. The Advanced Classes of the Town of Paris (Cours Supérieur de la Ville de Paris) was legally recognized with effect from 30 May 1903. The Circle operated quite well until the death of Demenij in 1917. With its founding in 1908 it achieved success in its duty (12 January 1908) to teach school children aged 11-18 (collèges and lycées). The Advanced Aptitude Certificate was the qualification required for teaching primary school children and older pupils to the age of 18, and for higher primary schools and the school leaving certificate the Aptitude Certificate was sufficient. The Advanced level Certificate was required for training teachers and former military specialists in anatomy and physiology of effort. Classes were also given by the Joinville school, which, on 10 December 1925, became the Advanced Physical Education School (Ecole Supérieure d'Education Physique).

However, the first formal training for teachers transferring to the field of physical exercises occurred at the time a waiver training course was opened. This occurred on 10 December 1927 through the impetus of Edouard Herriot (1872-1957), Minister for Public Instruction and Tissié, who was working at the Bordeaux medical school. The initial one-year training course was given at the Regional Institute for Physical Education, and attended by a group of 15 students [83], for the most part already teachers or holders of either the Vocational Diploma for Primary School (Brevet Supérieur du primaire) or the Secondary School Baccalauréat. The curriculum included anatomy, physiology, child psychology, pedagogy and bodily techniques (neo-Swedish gymnastics, physical education, the natural method, sport, in brief: the French Method.) It gave rise, after dissemination throughout France (Paris, Lille and Lyon on 9 June 1928 ; Nancy, Strasbourg, Toulouse, Aix-Marseille, and Montpellier on 28 April 1929, Grenoble in 1932), to the creation of a Physical Education Aptitude Certificate (Certificat d'Aptitude d'Education Physique) on 12 August 1931 with the French Method being the principal focus.

In Paris, qualifying for this certificate (IREP) established on 23 June 1933 was to be taught at the National Physical Education School in rue Lacretelle, which at the time was a select, high achievement university college (Ecole Normale Supérieure) giving advanced training courses. The advent of the IREP certificate led on 31 July 1933 to establishing the Certificate of Aptitude for Teaching Physical Education (Certificat d'Aptitude au Professorat d'Education physique), a two-year course of study subsequent to achieving the Vocational Diploma for Primary School or the Baccalauréat for Teaching in Secondary School. Generally speaking, the students for this course were already qualified primary school teachers.

Transfers to this new teaching structure ended with the 1939-1945 war which saw the closure of the Joinville School, the creation in the Free Zone of the Monitors' College of Antibes (for both men and women) and the 15 General and Sports Education Regional Centers (Centres régionaux d'Education Générale et Sportive). The teacher training colleges and Advanced Teacher Training Establishments (Ecoles Normales supérieures) were closed during the German occupation (by decree of 15 August 1941) and under the Vichy government. They were considered hotbeds of communism and Freemasonry. The second manager of the ENEP, Ernest Loisel, was removed from his post and forced 
to retire from office in 1941 as a result of the Secret Societies decree (19 August 1940 and 27 February 1941). However, the French Method, largely imbued with the natural method, remained the official method.

In Argentina during the period under consideration, the training of education instructors took place in two types of institution: military and civil. The Army School of Gymnastics and Fencing had been created in 1897 and was run by the Italian fencer Enrique Pini. It was closed in 1903 and reopened in 1925. The Higher Institute of Physical Education was the result of a gradual process of understanding the need to train schoolteachers to teach physical education at schools. To meet this need, on 8 October 1901 the Ministry of Justice and National Education founded by decree, the First Summer Course of Physical Education that would be available from December 1901 to February 1902 under Romero Brest's management. Those who were in charge of physical exercise at national schools and Normal Schools, teachers annexed to Normal Schools, and advance level students of Normal Schools were invited to attend this course [84]. Four more summer courses followed in 1902, 1903, 1905 and 1906. At the same time, three theoretical and practical courses of physical exercises were set up by decree in April 1902 to be undertaken by the teachers of the three Normal Schools in the city of Buenos Aires.

Romero Brest, having completed his medical studies and during the time he ran the courses and delivered theoretical and practical classes, designed his system for the Argentine Method of Physical Education. The Normal School of Physical Education was the result of the converting the Summer Course into a regular physical education course addressed to those who had obtained their teaching degree. Finally, the National Higher Institute of Physical Education, which was a further development of the aforementioned School, was also created through a National Executive decree. Under Romero Brest's management until 1931, the Higher Institute was a privileged environment from which the Argentine System of physical education expanded [85].

In addition to this Institute, the General Office of Shooting and Gymnastics should also be mentioned since many of its former students were key figures in the promotion and dissemination of military physical education, becoming fierce opponents of the Argentine System [86].

\section{THE CULTURAL REALM, NOMAD THEORIES AND LOCAL THEORIES}

This paper shows how integrated primary education, a minima Western, was made available to all. It also shows how the idea became Nomadic, spreading the availability of physical education and its institutional organization to many countries not only France and Argentina. It can be seen too that the Swedish and German methods and the English sports method, were discussed and debated as much in France as in Argentina.

Many writers were involved in the heart of the deliberations on structuring the activities and the institutional organizations for training physical education teachers both in France and in Argentina. Mosso, Tissié, de Coubertin, Lagrange, Demenij, Marey and Hébert took part in this debate over defining a national method in France as in Argentina. Grousset was also a political protagonist in France yet no trace of him is found in Argentina. The same applies to Hébert who seems to be scarcely discussed in deliberations in Argentina despite his international success at the International Physical Education Conference in Paris in 1913, and despite Romero Brest having attended his presentations [87].

In both countries the outcome of all these discussion was the setting up of an eclectic system, largely military at certain times, mainly Swedish at others, and largely naturalist (in France), somewhat integrating the practice of sport, which in France came to called the Méthode Française and in Argentina Sistema Argentino and a little later Método Unico. In both cases it is considered that a method drawing benefits from other systems should be adapted to the national temperament and therefore cannot replicate in extenso the practical exercises of other countries. In both examples there was local adaptation and recontextualization of the Nomad theories and practices.

\section{CONCLUSION}

There are numerous similarities in the way compulsory, free physical education was set up in primary school in France and Argentina. The laws in both countries making education generally free, secular and compulsory were almost synchronic and obviously included physical education.

The scientific discourse was similar; energy gained an important place as time passed. Yet other points in common can be found in these two countries, particularly the establishment of School Battalions, although with a gap of several decades. The writers involved were in many cases those cited above, but while it is evident that ideas traveled from France and Europe to Argentina, there seems to have been little movement in the other direction. The ideas of Romero 
Brest, although he was present at the International physical education Conference in Paris in 1913, were not debated or discussed in France except at the time the Conference was actually being held. There was also a controversy concerning the appropriation of such methods as the Swedish, military and German systems and on the incorporation of sport in physical education. Although not greatly discussed above, health and hygiene together with eugenics were also strong driving forces in setting up compulsory physical education and for defining its practical content. In these two examples the countries concerned finally drew up a national method that borrows from other methods but recontextualizes and finally "indigenizes" them.

Conversely, three significant differences are identifiable.

The first is the political context in which physical education developed as a school subject, the justification for its educational value and the effect this had on the selection of physical exercises for schools. In the case of Argentina, by the 1880 s the recently formed national State was striving to stabilize and trying to define a political framework for its organization with a consensus of all the provinces after 40 years of civil war. In this situation, the triumph of the Argentine System as a school method having suppressed military exercises - for 30 years - seems to have met the social needs of integrating immigrants and educating citizens for peaceable administration, abandoning the need to prepare soldiers in school to fight future wars.

The second difference relates to the State's office responsible for organizing school physical education in each country. Although in both countries teaching physical education came about with compulsory school attendance and both in France and Argentina members of the army, physicians and teachers held intense discussions, the resulting method was an eclectic summary of their views. In France physical education existed from the beginning of the period and was the responsibility of the Ministry of War. In Argentina - still with many debates and a great deal of effort - it was always the responsibility of the Ministry of Public Education. This can be explained by the weight of the medical corps within the State bureaucracy. The influence of the medical corps and the impact that scientific and positivist ideas had on the social engineering project was deemed necessary for the education and integration into a single national society of the range of nationalities and cultures that co-existed in the country.

The third aspect is related to the strength of the physical culture and physical education ideal in each country [88]. In the case of France the debate took place in an environment occupied by a significant number of individuals, specialists in physical exercise - physicians, physiologists, athletes, and members of the army - who discussed and argued over the definition of the best physical education based on empirical studies and laboratory work. It was a more organized arena and therefore may have been more independent of socio-political fluctuations. In Argentina, scientific physical education was approved by physicians, general teachers and intellectuals, all of whom were antimilitarist. But there was no critical mass of specialists in physical education, and those specialists who did exist were still organizing themselves. One reason Romero Brest attended conferences was to learn about European models at first hand, to become known and to build legitimacy in international forums. It was the liberal and socialist (pacifist and antimilitarist) teachers and intellectuals who supported the Argentine System and helped end the military method, and it was they who, until 1938, set the pace of the Nomad ideas in the recontextualization process in Argentina.

\section{CONFLICT OF INTEREST}

The authors confirm that this article content has no conflict of interest.

\section{ACKNOWLEDGEMENTS}

This work was supported by the GACR (contract P203/12/1896) and the ASCR (contract IRP AV0Z10480505).

\section{REFERENCES}

[1] Gleyse J. Archéologie de l'Education physique au XXe siècle en France. Paris: PUF 1995.; Kirk D, Ed. Schooling Bodies School Practice and Public Discourse 1880-1950. Leicester: University Press 1998.; Aisenstein Cuerpo A, Escuela y Pedagogía, Aisenstein A, Eds. Revista Iberoamericana. América Latina- España-Portugal 2003; 10: pp. 83-102.

[2] Meyer J, Ramírez F. The World Institutionalization of Education. In: Schviewer J, Ed. Discourse Formation in Comparative Education. Frankfort: Peter Lang 2000; pp. 47-59.

[3] Saint-Martin J. Educations physiques françaises et exemplarités étrangères entre 1815 et 1914. Paris: L'harmattan 2003.; Saint-Martin J, Ed. Educations physiques françaises et exemplarités étrangères entre 1815 et 1914. Paris: L'harmattan 2003.; Soares C, Dalben A, Gleyse J, Eds. Educations physiques françaises et exemplarités étrangères entre 1815 et 1914. Paris: L'harmattan 2003.; Soares C, Dalben A, Gleyse J, Eds. Estudo comparativo da recepção do Método Natural de Georges Hébert no Brasil e na França: 2013: Procedings of Physical Education and sport around the Globe: past, present and Future; Gama Filho University; pp 107-119; Scharagrodsky . Rio de Janeiro, Brazil: L'harmattan 
2012. [July 4-8 ${ }^{\text {th }}$;; Scharagrodsky P, Gleyse J, Eds. Estudo comparativo da recepção do Método Natural de Georges Hébert no Brasil e na França: 2013: Procedings of Physical Education and sport around the Globe: past, present and Future; Gama Filho University; pp 107-119; Scharagrodsky . Rio de Janeiro, Brazil: Gama Filho University 2012; pp. [July 4-8th];107-19.; Scharagrodsky P, Gleyse J, Romero Brest El Dr Enrique, Eds. las visitas a instituciones europeas de formación y el Congreso de Educación Física realizado en 1913 como indicadores de la globalización y la nacionalización de la "cultura física", STAPS International Journal of Sport Science and physical éducation . 2013; 100: pp. 52-75. STAPS International Journal of Sport Science and physical éducation Aisenstein A 2003; 10: 83-102.

[4] Seurin P. L'Education physique dans le monde, Bordeaux: Bière 1961; Legrand F and Ladegaillerie J, L'Education physique au XIXe et XXe siècle à l'étranger. Paris: Armand Colin 1965.

[5] Gleyse J. L’Education physique dans le monde, Bordeaux: Bière 1961 In: Saint-Martin J, Ed. Educations physiques françaises and exemplarités étrangères entre 1815 and 1914. Paris: L'harmattan 2003; pp. 143-59.

[6] Gleyse J, Ed. Saint-Martin J.Georges Demenij et la modernisation de la gymnastics médicale de P.-H. Ling Educations physiques françaises and exemplarités étrangères entre 1815 and 1914. Paris: L'harmattan 2003; p. 145.

[7] Scharagrodsky P, Gleyse J. las visitas a instituciones europeas de formación y el Congreso de Educación Física realizado en 1913 como indicadores de la globalización y la nacionalización de la "cultura física STAPS. Inter J Sport Sci Phys Éduc 2013; 52-75.

[8] Gleyse J, Soares C, Dalben A. 107-119. Scharagrodsky P and Gleyse J 2013; 2013: 58.

[9] Terret T, Tesche L. French gymnastics in Brazil: dissemination, diffusion and relocalisation. Int J Hist Sport 2009; 13(26): 1983-98. [http://dx.doi.org/10.1080/09523360903148820]

[10] Gleyse J. Soares C, Educacao Física. Raízes Européias e Brasil. Campinas: Editora Autores Asociados 1994; Kirk D, 1998; Scharagrodsky P. Los ejercicios militares en la escuela argentina: modelando cuerpos masculinos y patriotas a fines del siglo XIX: In: Aisenstein A and Scharagrodsky P Eds. Tras las huellas de la Educación física escolar argentina. Cuerpo, género y pedagogía. Buenos Aires. Prometeo (Milan) 1995; 2006: 26-38. [Among many others.]

[11] Meyer JW, Kamens D, Benavot A. School knowledge for the masses World models and national primary curricular categories in the twentieth century. London: The Falmer Press 1992.

[12] Defrance J. Préface. In: Gounot A, Jallat D, Caritey B, Eds. Les politiques au stade Etude comparée des manifestations sportives du XIX au XXI siècle PUR. Rennes 2007; pp. 7-11.

[13] Coll. Declaration of independence from Spain Signed in San Miguel de Tucumán on 9 July 1816. Available from: https://fr.wikipedia.org/wiki/Congrès_de_Tucumán\#/media/File:Acta_Independencia_argentina_quechua.jpg 1816 [(accessed July $25^{\text {th }}$ 2016).];

[14] Religious education shall solely be delivered in public schools by the authorized ministers of each cult to children of the corresponding religious belief, before or after school schedule (Act number 1420 of common education) 1884 Section $8^{\circ}$ [8 July 1884].

[15] INDEC. http://www.indec.gov.ar/glosario/glosario_faq.asp [(accessed 20 march 2011)];

[16] Zapiola MC. Niños en las calles: imágenes literarias y representaciones oficiales en la Argentina del Centenario. In: Gayol S, Madero M, Eds. Formas de Historia cultural. Buenos Aires: Prometeo-UNGS 2007; pp. 305-32.

[17] Bertoni LA. La Escuela y la formación de la nacionalidad a fines del siglo XIX In: Coll Boletín del Instituto de Historia Argentina y Americana. 1996; 13.; Bertoni LA. Soldados, gimnastas y escolares: defender la nación In: Patriotas, cosmopolitas y nacionalistas La construcción de la nacionalidad argentina a fines del siglo XIX. : Fondo de Cultura Económica: Buenos Aires 2001; pp. 213-54.

[18] Romero Brest E. Evolución de la Educación física en la escuela argentina. Revista de la Educación Física 1910; año II(11-12): 554-5.

[19] Arnaud P. Le Militaire, l'écolier, le gymnaste Naissance de l'éducation physique en France (1869-1989). Lyon: PUL 1985.

[20] Official Instruction of 1st June 1941 and known as Education Générale et Sportive - EPS 1941.

[21] Arnaud P. Le Militaire, l'écolier, le gymnaste Naissance de l'éducation physique en France (1869-1989), Lyon: PUL 1985; Gleyse J Archéologie de l'Education physique au XXe siècle en France. Paris: PUF 1995.

[22] Manuel d'exercices gymnastiques et de jeux scolaires. Paris: Hachette 1890; 1.

[23] Manuel d'exercices gymnastiques et de jeux scolaires. Paris: Hachette 1890; 6.

[24] Brandao de Sousa Mendes MI. Mens sana in corpore sano. Natal: Editora Sulina 2007.

[25] Gleyse J. L'Instrumentalisation du corps Une archéologie de la rationalisation instrumentale du corps de l'Age Classique à l'époque hypermoderne. Paris: L'harmattan 1997.

[26] Manuel d'exercices gymnastiques et de jeux scolaires. Paris: Hachette 1890; 4.

[27] Fournier L. Règlement d'Education physique. Paris: Librairie Militaire 1910; 7.

[28] Fournier L. Règlement d'Education physique. Paris: Librairie Militaire 1910; 8.

[29] Projet de réglement général d'Education physique1. Paris: Librairie Militaire 1919; 21. Méthode française

[30] Instructions officielles ministérielles du 1er Juin 1923, Journal officiel. Paris: 1923; 8.

[31] Aisenstein A. La Educación Física en la Escuela Primaria. 1880-1930.; Ascolani A, Ed. Historia de la Educación. Rosario: Ediciones del Arca 1999; pp. 53-74.; Saraví Riviere J, Ed. Historia de la Educación Física Argentina Siglo XIX,. Buenos Aires: INEF 1986. 
[32] Saraví Riviere J. Historia de la Educación Física Argentina Siglo XIX. Buenos Aires: INEF 1986.

[33] Argentina, Decree issued by the national Executive Power Plan de Enseñanza de Educación Física nacional [Teaching Plan for national Physical Education] 1905. passed on 17 Feb

[34] Romero Brest E. Pedagogía de la Educación Física. $3^{\mathrm{a}}$ edición ampliada y corregida. Buenos Aires: Librería del Colegio $1915 ; 156$.

[35] Romero Brest E. Pedagogía de la Educación Física. 3a edición ampliada y corregida. Buenos Aires: Librería del Colegio 1915; pp. 109-10.

[36] Consejo Nacional de Educación. Programa para las Escuelas Comunes de la Capital Federal. Buenos Aires 1936 ; pp. 13-4.

[37] Ministry of Justice and Public Education. Programa de Educación Física para Escuelas Nacionales. Buenos Aires: Normales y Especiales 1942; pp. 59-60.

[38] Fresco M. La educación física: una innovación de mi gobierno. In: Tomo I, Ed. Sus fundamentos y su aplicación. Buenos Aires:: Talleres gráficos Damiano 1940; 87: pp. 90-100.

[39] Gómez Dagfel P. La educación física en la legislación argentina. In: El itinerario normativo de una asignatura escolar (1880- 1950) . Universidad de Salamanca: Tesis de Maestría en Educación Física 2004.

[40] Levene H. Gimnasia metodizada Método Años 1924-1938. Buenos Aires: Orientación Integral Humana. SRL, Sección Editorial 1939; p. 25.

[41] Romero Brest E. Cursos Normales de Educación Física. Buenos Aires: Las Ciencias Librería y Casa Editora de Nicolás Marana 1903; pp. $56-7$.

[42] Romero Brest E. Cursos Normales de Educación Física. Buenos Aires: Las Ciencias Librería y Casa Editora de Nicolás Marana 1903 ; p. 10.

[43] Scharagrodsky P. La constitución de la educación física escolar en la Argentina. Tensiones, conflictos y disputas con la matriz militar en las primeras décadas del siglo XX. In: Scharagrodsky P, Ed. La invención del 'homo gymnásticus' Fragmentos históricos sobre educación de los cuerpos en movimiento en Occidente. Buenos Aires: Prometeo 2011; pp. 441-77.

[44] Saraví Riviere J, Aisenstein A, Scharagrodsky P, Eds. Aportes para una historia de la Educación Física. Buenos Aires: INEF 1998 19001945. 1999, 2006, 2006

[45] Scharagrodsky P. La constitución de la educación física escolar en la Argentina. Tensiones, conflictos y disputas con la matriz militar en las primeras décadas del siglo XX. In: Scharagrodsky P, Ed. La invención del 'homo gymnásticus' Fragmentos históricos sobre educación de los cuerpos en movimiento en Occidente. Buenos Aires: Prometeo 2011; pp. 447-8.

[46] $100^{\text {th }}$ anniversary of the creation of the First National Government. 1810 [on 25 May];

[47] This journal was the official publication of the Higher or National Institute of Physical Education and was edited in three different and successive stages: the first time, between 1909 and 1916; the second, from September 1921 to March 1931; and the third, in 1936

[48] Romero Brest E. Evolución de la Educación física en la escuela argentina. In: Revista de la Educación Física. 1910; II : pp. (11-12)323-4.

[49] See Aisenstein A. La Educación Física en la Escuela Primaria (1880-1930). In: Ascolani A, Ed. Historia de la Educación. Rosario: Ediciones del Arca 1999; pp. 53-74.

[50] Aisenstein A. La Educación Física en la Escuela Primaria (1880-1930). In: Ascolani A, Ed. Historia de la Educación. Rosario: Ediciones del Arca 1999; pp. 53-74.

[51] Aisenstein A. La higiene y la educación del cuerpo en el Congreso Pedagógico Sudamericano de In: Anuario Sociedad Uruguaya de Historia de la Educación 2012. 1882. Año 1; 1

[52] Tissié P. Gymnastes et sportifs, Revue Scientifique (Revue Rose). Tome III, 5ème série, 18 mars 1905; $11 ; 327$.

[53] Demenij G. Preface. In: Colonel L, Ed. Méthode de gymnastique Educative Suédoise. Paris, Bruxelles: Lebègue et Cie et Alcan 1903 ; p. 6.

[54] The writer specifically uses the spelling Demenij here, in accordance with the Flemish rendering of his name — and not Demeny or Demenÿ. In: Furthermore, note that the racist, anitsemitic attack on Georges Demenij as a 'Hungarian Jew' by Raoul Fournié, in The Healthy Man (L'Homme Sain) 2, in 1940, has even less justification since a recent work on cinematic origines; Manoni L Demenÿ, Cinematographic Pioneer (Demenÿ. 1997. clearly confirms the Flemish origins of his surname.

[55] Demenij G. Sur l'évolution de l'éducation physique en France. Revue Scientifique, (Revue Rose), Tome IV 1905394 [13, 23 septembre];

[56] Demenij G. 1890De la précision des méthodes d'éducation physique, Revue Scientifique, (Revue Rose), Tome XLVI 1905354: 355-6. [12, 20 Septembre];

[57] Demenij G. De la précision des méthodes d'éducation physique. Revue Scientifique 1890; XLVI(12): 358. [12, 20 Septembre].

[58] Gleyse J. L’Instrumentalisation du corps Une archéologie de la rationalisation instrumentale du corps de l'Age Classique à l'époque hypermoderne. Paris: L'harmattan 1997.

[59] Demenij G. De la précision des méthodes d'éducation physique. Revue Scientifique (Revue Rose) 1890; Tome XLVI(12): 353-4. [12, 20 Septembre].

[60] Demenij G. L’Education physique en Suède. Paris: Alcan 1892; p. 127.

[61] Tissié P. L'Education physique, Préface In: Tissié P, Ed. L’Education physique au point de vue historique, scientifique, technique, critique, pratique \& esthétique. Paris: Librairie Larousse 1901 XXVII. 
[62] Tissié P. L’Education physique, Préface In: Tissié P, Ed. L'Education physique au point de vue historique, scientifique, technique, critique, pratique \& esthétique. Paris: Librairie Larousse 1901 XXXI.

[63] Tissié explained, in 1919, that: 'I lacked the support of Public Instruction from 1903, the time when I published in the Revue Scientifique the critical study of the Regulation on Gymnastic Instruction of 22 October 1902. Paris: L'Education physique et la race Flammarion 1919 ; 310. Having alerted the Minister of the error he was making in P.E., not only was I not listened to, but I was sent away.'

[64] Tissié P. L’Education physique et la race. Paris: Flammarion 1919; p. 152.

[65] Tissié P. L'Evolution de l'éducation physique en France et en Belgique (A propos de deux méthodes d'éducation). Revue Scientifique 1903; II(24): 744.

[66] Tissié P. L'Evolution de l'éducation physique en France et en Belgique (A propos de deux méthodes d'éducation). Revue Scientifique 1903; II(24): 745 .

[67] Demenij G. Les Bases scientifiques de l'éducation physique. Paris: Alcan 1902; p. 101.

[68] Tissié P. L'Evolution de l'éducation physique en France et en Belgique (A propos de deux méthodes d'éducation). Revue Scientifique 1903; II(24): 748 .

[69] Lagrange F. Physiologie des exercices du corps. Paris: Alcan 1888; p. 28.

[70] Coll (Academy of médicine) Official Report of 16 Dec. Paris 1890; 12. Imprimerie Nationale 1890

[71] Durry J. Le Vrai Pierre de Coubertin. Paris: Comité Français Pierre de Coubertin 1997; p. 36.

[72] Durry J. Le Vrai Pierre de Coubertin. Paris: Comité Français Pierre de Coubertin 1997; p. 34.

[73] Durry J. Le Vrai Pierre de Coubertin. Paris: Comité Français Pierre de Coubertin 1997; p. 52.

[74] Hébert G. L'Education physique virile et morale par la Méthode naturelle Tomes 1 à 10. Paris: Vuibert 1936-1957.

[75] Hébert G. Le Sport contre l'éducation physique. Paris: Vuibert 1925.

[76] Hébert G. L’Education physique virile et morale par la Méthode naturelle. Paris: Vuibert 1936.

[77] Stepan N. A hora da Eugenia: raça, gênero e nação na América Latina. Rio de Janeiro: Fiocruz 2005.

[78] Vallejo G. Roma-Buenos Aires: un eje para la expansión de la biotipología y el fascismo (1922-1939). In: Vallejo G, Miranda M, Eds. Derivas de Darwin: Cultura y Política en clave biológica. Buenos Aires: Siglo Veintiuno 2010; pp. 71-96.

[79] Romero Brest E. Pedagogía de la Educación Física. 33 edición ampliada y corregida . Buenos Aires: Librería del Colegio 1915.(4-5):

[80] Wernicke B. Juegos escolares para las niñas, Buenos Aires:. Buenos Aires: Angel Estrada y cía 1904.(5-6): Editores

[81] Carrel A, Man. Man, this unknown. New-York: Double day 1939. pref. XI

[82] Richet C. La selection humaine. Paris: Alcan 1919; p. 14.

[83] Robène L. Itinéraire d'une « prof de gym ». Paulette Morisson (1914-2000). In: Sport et Genre, Volume 3 Apprentissage du genre et institutions éducatives. Paris: L’Harmattan 2005; pp. 319-37.

[84] Saraví Riviere J. Historia de la Educación Física Argentina Siglo XIX. Buenos Aires: INEF 1986; p. 43.

[85] Saraví Riviere J. Historia de la Educación Física Argentina Siglo XIX. Buenos Aires: : INEF 1986.; Aisenstein A Cuerpo, Escuela y Pedagogía, Eds. Revista Iberoamericana. América Latina- España-Portugal 1986; 10: pp. 83-102.; Scharagrodsky P, Ed. Los ejercicios militares en la escuela argentina: modelando cuerpos masculinos y patriotas a fines del siglo XIX. América Latina- España-Portugal 1986; 10: pp. 83-102.; Scharagrodsky P, Aisenstein A, Eds. Tras las huellas de la Educación física escolar argentina. Buenos Aires:: Prometeo Cuerpo, género y pedagogía 2006; 10: p. 26.

[86] Scharagrodsky P. La constitución de la educación física escolar en la Argentina. Tensiones, conflictos y disputas con la matriz militar en las primeras décadas del siglo XX. In: Scharagrodsky P, Ed. La invención del ‘homo gymnásticus’ Fragmentos históricos sobre educación de los cuerpos en movimiento en Occidente. Buenos Aires: Prometeo 2011; p. 442.

[87] Scharagrodsky P, Gleyse J, Enrique Romero Brest, Eds. las visitas a instituciones europeas de formación y el Congreso de Educación Física realizado en 1913 como indicadores de la globalización y la nacionalización de la "cultura física", STAPS International Journal of Sport Science and physical éducation 2013; 100; 52-75 2013; 100: 52-75. Aisenstein A 2003; 10: 83-102

[88] Bourdieu P, Ed. According to Bourdieu. Its structure is a state of relationship of forces between the agents and institutions that are involved in the struggle for such definition and for the distribution of the specific capital that has been accumulated during previous truggles and that guides future strategies. México: Grijalbo.: Sociología y cultura 1990.

(C) Aisenstein and Gleyse; Licensee Bentham Open

This is an open access article licensed under the terms of the Creative Commons Attribution-Non-Commercial 4.0 International Public License (CC BY-NC 4.0) (https://creativecommons.org/licenses/by-nc/4.0/legalcode), which permits unrestricted, non-commercial use, distribution and reproduction in any medium, provided the work is properly cited. 